Accounting and Management Information Systems

Vol. 18, No. 3, pp. 399-416, 2019

DOI: http://dx.doi.org/10.24818/jamis.2019.03005

\title{
Corporate climate change reporting: Evidence from Bangladesh
}

\author{
Mofijul Hoq Masum ${ }^{\mathrm{a}}$, Nazmul Hassan ${ }^{\mathrm{b}}$ and Tasnin Jahan ${ }^{\mathrm{a}}$ \\ ${ }^{a}$ School of Business and Economics, United International University, \\ Bangladesh \\ ${ }^{\mathrm{b}}$ East West University, Bangladesh
}

\begin{abstract}
Research Question: Do the Bangladeshi business entities concern about the extreme climate change vulnerability of the country? How do they deal with the climate change issues in their corporate reporting? Motivation: As per the Climate Change Vulnerability Index 2014, Bangladesh is one of the most vulnerable countries in the world. To cope up this extreme stage not only the government but also all the stakeholders of the country should come forward. This study aims at exploring the attention of business organizations of Bangladesh toward the climate change issues of the country. Idea: When developed nations realized and shared accountability in relation to the adverse effect of climate change, developing nation pay less attention towards the impact of climate change and environmental degradation (Luo et al., 2013; Amran et al., 2014; Jeswani, 2007). Ironically, academic have paid less attention to examine the organizational efforts towards sustainability and environmental safety in the context of developing countries (Kabir \& Akinusi, 2012). This research is intended to explore climate change reporting practices in developing countries - Bangladesh. Data: A purposive sampling of 82 companies listed in the Dhaka Stock Exchange (DSE) has been taken based on the year 2016 or 2015-2016. Tools: An un-weighted Climate Change Disclosure Index (CCDI) has been constructed and used to understand the climate change disclosure level practiced by selected companies. Findings: we have found a very poor disclosure levels practiced
\end{abstract}

${ }^{1}$ Corresponding author: Mofijul Hoq Masum, Assistant Professor, School of Business and Economics, United International University, phone: +88-01558965046, Email: masum.ais@gmail.com 
by the Bangladeshi listed companies as the mean climate change disclosure index (CCDI) is only 3.02 out of the maximum possible score of 28 . Surprisingly, heavily polluting industries have very poor climate change disclosure indices compared to the non-polluting industries. Contributions: The study will create awareness to all the stakeholders of the climate change issues so that a holistic approach can be executed not only to accelerate the literatures on climate change but also to ensure sustainability on corporate climate change reporting.

Keywords: Climate change disclosures, sustainability reporting, content analysis, listed companies.

\section{JEL codes: Q50; Q54; M1}

\section{Introduction}

Climate changes, as an emerging and dominant phenomenon in society, with its adverse effect on the environment and humanity, turns into the greatest concerns to the survival of all lives on earth. It is a global challenge. The United Nations Framework Convention on Climate Change (Declaration of the UN Conference on the Human Environment, 1992, p. 3) defines climate change as:

"A change of climate which is attributed directly or indirectly to human activity that alters the composition of the global atmosphere and which is in addition to natural climate variability observed over comparable time periods."

The severe consequence of climate change has drawn increased attention to the identification of approaches to deal with the adverse effects of climate changes (Wilmshurst \& Frost, 2000). One of the primary reasons for environmental degradation and climate change is industrial pollution. In addition, business organizations are fundamentally accountable for the adverse effect of climate change (Ahmad \& Hossain, 2015; Nurunnabi, 2016). Thus, Business organizations should perform activities to the protection of natural resources and sustainable environment. Because of the proliferation in social concern relating to the harmful effects of climate change aligned with the growth of environmental activism, persuade companies to respond to such escalating environmental agenda (Ferguson et al., 2016). Companies are struggling to prove their stand against industrial pollution. It is expected that companies would acknowledge the detrimental effects of industrial pollution on the climate. In an attempt of that, companies are starting to communicate their action, position and awareness on climate change through the company's 
annual report, website, meeting, and conference. Tilt (1997) emphasizes the addressing of corporate responsibility and accountability to the sustainable environment through corporate communications. Although, such kind of communication or disclosure is voluntary in nature by business entities. Allen and Craig (2016) urged the necessity of corporate social responsibility (CSR) from being the voluntary luxury in the age of climate change. Corporate reasonable engagements to society and environment is perceived as an instrument of accountability and transparency (Fijałkowska et al., 2018).

The business entity attempts to publicize corporate responsibility and accountability relating to the environment and sustainability, thus resulting in the relationship between corporation and stakeholders (Wilmshurst \& Frost, 2000). This attempt also creates a positive image of the corporation to the society. Fijałkowska et al. (2018) see such engagement to society and environment as competitive advantage. Deegan and Rankin (1999) urged the importance of disclosing such information, so that stakeholders can consider such voluntarily disclosed information in various decision-making including investment, lending, and consumption decision. One of the reasons for non-disclosure of such kind of CSR in annual report of developing country is maintaining privacy about the activities of company. Empirical study claims that companies of developing countries prefer to disclose more positive new than negative news (Deegan \& Rankin, 1996). Therefore, if there is lack of positive news there is lack of corporate social reporting (Belal \& Cooper, 2011). They also noted that such reporting might demand additional scarce resources in terms of both time and money.

Corporations are under pressure to reduce carbon emission and disclose initiative taken to environmental sustainability. Stakeholders are also putting pressure on business to disclose information regarding environmental safety activities. Thus, the notion of voluntary disclosure of environmental information got the attention that is demonstrating the business environmental responsibility through its consistent work. The Climate Disclosure Standards Board (CDSB) works to publicize environmental information to stakeholders. It also offers a framework for reporting environmental information through mainstream financial reports. With its experience and technical expertise, CDSB supports companies and regulatory bodies to implement the CDSB framework in respect of organizing and disclosing environmental information for the aid of stakeholders. Therefore, it is expected that like other entities of the society, corporations should also comply with the rules and regulations following the standardized framework.

However, Dunn (2002) found that escalating pressure towards climate safety and sustainability varies substantially from country to country. Previous studies have focused on the sustainable activities of large international corporations of developed countries (Sobhani et al., 2009). Deegan (2002) amplifies this claim as mentioned 
the developed countries' organizations have been the subject of substantial academic research in the field of social awareness and environmental reporting. Ironically, researchers have paid less attention to examine the organization efforts towards sustainability and environmental safety in the context of developing countries (Kabir \& Akinnusi, 2012).

This paper is an attempt to explore climate change reporting practice in developing countries. It is also worthy to note that developed nations are legally sound to counter climate change and to fight the adverse effect of climate change (Nurunnabi, 2016). Therefore, developed nations are forcing companies for legal compliance about environmental disclosure (UN Framework Convention on Climate Change, 2014). The extant literature urges the legal compliance of climate change reporting. Most of the cases legal requirements are only effective if they are properly enforced. Therefore, Nurunnabi (2016) noted the importance of government intervention to enforce companies in the developing countries. Nonetheless, there will be low levels of climate change disclosure.

Corporate climate change reporting is a vital issue for Bangladesh nowadays; it becomes graduated by the UN from under developing countries to developing countries. As per the UN environment and infrastructure indicators, estimated CO emission (million tons/tons per capita) in Bangladesh increased to 73.2 / 0.5 in 2018, which was 39.5 / 0.3 in 2005. Moreover, according to the annual climate risk index of 2017, Bangladesh holds a ninth position among the most affected countries. It is evident from the climate risk index of 2017 that South-Asian countries are the most affected due to the adverse effect of climate change. It is worth mentioning that less developed countries are more vulnerable than in developed countries. The report documented that out of 10 most affected countries, eight are from the developing countries. Therefore, companies operating in developing countries should become more accountable for their action to climate change.

However, adherence to societal obligation and disclosure of information about an organizational strategic approach to minimize the hazardous effect of climate change strengthen the organizational competitiveness in market. Yet, research on climate change and related disclosure in the context of developing countries are still in its elementary (Ahmad \& Hossain, 2015) and most of them were concentrated on the nature and extent of disclosure, identifying the determinants of climate change disclosure (Ahmad \& Hossain, 2015; Sobhani et al., 2009). This study is distinct and unique in the sense that it explores the climate change reporting practices of the listed companies of one of the most environmentally vulnerable area - Bangladesh. In addition, this study will provide an insight into the specific awareness regarding the climate change in developing countries. Besides, from the findings of the study, stakeholders and regulatory bodies have an understanding of the focus of the climate change issues of the corporate people in the developing countries. The main 
objective of this research is to analyze the nature and extent of disclosures regarding climate change of Bangladeshi listed companies.

The study is organized as follows. The following section presents the existing literature of climate change along with various factors determine the corporate responses to climate change and its disclosures in developed and developing counties. In the next section, content analysis and methodological steps taken for preparation of climate change disclosure index (CCDI) have been presented. Next, the result of climate change disclosure index (CCDI) and thorough explanation of industry wise and category wise average disclosure level of climate change by sample companies are given. The last section of the paper includes the concluding remarks and opportunities for further researches regarding climate change practices are mentioned.

\section{Literature review}

In recent decades, environmental and climate change disclosure is a vital area of research in the field of environmental accounting (Gibson \& O'Donovan, 2007; Nurunnabi, 2016; Rahman et al., 2010; Dey et al. Dutta, 2017; Ahmad \& Hossain, 2015). As the societal concern over environmental degradation and adverse effect of climate is escalating, accordingly, the number of studies to deal more effectively with adverse effects of climate changes has been growing. (Kılıç \& Kuzey, 2019; Rainsbury et al., 2016; Sobhani et al., 2009; Ferguson et al., 2016). When developed nations realized and shared accountability in relation to the adverse effect of climate change, developing nation pay less attention towards the impact of climate change and environmental degradation (Luo et al., 2013; Amran et al., 2014; Jeswani, 2007). Regarding this Deegan (2002) noted that developed countries have been the subject of substantial academic research. Ironically, academic have paid less attention to examine the organizational efforts towards sustainability and environmental safety in the context of developing countries (Kabir \& Akinusi, 2012).

As per the Climate Change Vulnerability Index 2014, Bangladesh is one of the most vulnerable countries in the world. To cope up this extreme stage not only the government but also all the stakeholders of the country should come forward. Having insight on the urgency of environmental reporting Imam (2000) examined corporate social and environmental reporting practice in Bangladesh. The study noted that most companies did not provide any information regarding environmental, human resources, community, and consumers related activities. The study found only nine companies (representing $22.5 \%$ of the total sample) disclose information regarding environmental safety activities and the remaining did not show any concern for environmental issues. In addition, this study also noted that companies have shared selective information, mainly, positive and qualitative information about 
contributions made by the companies to the environment. In a similar study on Corporate Social and Environmental Disclosure (CSED), Sobhani et al., (2009) constructed a disclosure index considering 100 listed Bangladeshi companies and found that around $100 \%$ of the companies disclosed at least one item related to Human Resource (HR) disclosure. They also find that nineteen percentage of sampled companies are disclosing environmental information. This result may indicate that unlike the environmental issue, human resource is one of the most important stakeholders that can create pressure for CSED to the organizations. In addition, the examination of total sentences disclosed in the annual report reveals that $90 \%$ of them are describing the positive news while only $2 \%$ of sample companies disclose negative news.

A similar result also reported by Belal (2000) in a study on environmental reporting practice in Bangladesh. It shows that environmental disclosure has been made by companies are very limited (only $20 \%$ of representative companies). In most of the cases, Information disclosed are mostly descriptive in nature and positive news about the initiative taken by the companies. The study also noted that quantity of disclosed information is inadequate compared to information disclosed in the developed countries. This lesser extent of disclosed information in the annual report might indicate the lack of effectiveness in the case of implementation of the regulation in Bangladesh. Most of the case inadequacy of regulatory framework is also observed. Although the number of business entities acknowledged their accountability for the adverse effect of climate change is very little. Corporates are doing so either for the intense pressure of stakeholders or for the accountability to society. In most of the case corporate perceived such social engagement and environmental innovation as additional cost that lower profitability of corporate (Fijałkowska et al., 2018). However, Hossain et al. (2015) noted that Business organization is counted such reporting practice as a social obligation. Interviewing companies' available annual reports, Hossain et al., (2015) report that managers, as a part of social obligation, focus on disclosing mostly few specific environmental activities. Absence of institutional pressure and lack of regulation result in reluctances of disclosure of environmental information. Even though the limited disclosure practiced has observed among organizations, the study noted that Bangladeshi organizations do not disincline to disclose information in relation to the environment and human rights. However, the presence of proper implementation and enforcement of regulation might increase the extent of discloser in the corporate annual report. This voluntary disclosing practiced is encouraged by the Central Bank of Bangladesh. Even though the extent of disclosure was less satisfactory, and standard of disclosure was not adequate. Regarding this fact, Belal (2000) affirms the notable efforts made by Bangladeshi companies in the new area of reporting.

In a study on companies' accountability regarding climate change in Bangladesh, Nurunnabi (2016) conducted 31 semi-structured interviews and examined 71 annual 
reports. The study demonstrated climate change reporting in Bangladesh is relatively low. In addition, it is evident from the study of Nurunnabi (2016) that compare to other, large companies emphasize reporting their activities towards environmental safety and climate change in their annual report. In order to hold a legitimate position in the market, companies disseminate information relating to their notable efforts of environmental safeguards and social awareness. Nurunnabi (2016) raised a question about the lack of climate change reporting and motive towards business entities operating in Bangladesh, most adversely affected country in the world, while ignoring the environmental and social accountability. However, unlike the case of the developed countries' the extent of disclosure levels regarding climate change and environmental protection is relatively low in developing countries (Nurrnaabi, 2016; Khan et al., 2011).

According to Margolis et al. (2007), public perceives the companies contributing in non-profit activities as a responsible citizen of society. In addition, society gives benefit to companies in terms of products, jobs and expansion. Therefore, it improves the financial performance of companies. It has seen that contemporary literature on CSR research signified a movement (proceed) towards investigating relationship between CSR disclosures with organizational performance from the determination of the quality of CSR activities of the organization. Study shows the inconclusive findings about determinants of CSR in emerging economies (Rahman \& Momin, 2009). Developed countries have studied extensively to find the association between corporate performance with extent and quality of disclosure. Whereas developing countries still show less attention to investigate the relationship between corporate environmental performance and corporate financial performance (Fijałkowska et al., 2018). For example, study on china companies' reveal that both poor and good performing companies tend to disclose more environmental information. It is also found empirically that listed companies with strong financial performance disclose more information regarding social activities in the annual report than less performer. In the context of Bangladesh, Rashid (2018) reported that even though disclosure of CSR influences firm performance but firm performance does not influence in case of disclosing corporate and social information. Fijałkowska et al. (2018) also confirms similar finding from their empirical analysis.

This study aims at exploring the attention of business organizations of Bangladesh toward the climate change issues of the country. The current study depicts the phenomena of corporate reporting regarding the climate change issues in developing countries, especially in Bangladesh. According to our study, a very poor disclosure level practiced by the Bangladeshi listed companies is found and the mean climate change disclosure index (CCDI) is only 3.02 out of the maximum score of 28 . The highest score is 12 which is attained Telecom Industry and Bank \& Finance Industry provide second highest CCDI score of 8.63. Surprisingly, heavily polluting industries such as Fuel \& Power, Paper \& printing, Tannery, Cement, etc. have very poor climate change disclosure indices which also complied with the previous works 
of literature. The findings reveal that still the polluting industries become far behind regarding the climate change issues. In addition, the non-polluting industries are performing comparatively well with the climate changing issues but with a very minimum level.

\section{Methodology}

To conduct the study, a purposive sample of eighteen industries has been selected. All the industries are not selected as a sample because their formation and operating structure are not same even some the industries have customized law regarding their financial reporting. In addition, in Bangladesh, especially Dhaka Stock Exchange (DSE) all the annual reports are not available for 2016.

Therefore, out of a population of three hundred and four companies eighty-two companies are selected finally based on the following criteria:

a. The said companies have regularly published their annual report.

b. The concerned companies are from the selected eighteen industries.

c. The selected companies are not from " $Z$ " categorized company (categorized by DSE).

Finally, a sample of 82 companies out of 304 companies of 18 different industries listed in the Dhaka Stock Exchange (DSE) has been taken to conduct the study. A detail of the sample design has been given on Table-1 and shown in Appendix. To measure the climate change reporting of the selected samples, annual reports are used as the main source of information. The annual report has been selected as a source of secondary data because it is more reliable and available (Masum et al., 2019; Gray et al., 2001). All the annual reports used in the study has been selected for the year 2016 or 2015-2016.

A content analysis of twenty-eight different items concerning climate change is used. Twenty-five of the items have been directly taken from the previous literature and the rest three items have been chosen as the sample companies frequently disclose these items. Content analysis is widely used by numerous researchers (Masum et al., 2019; Dey et al., 2017; Rahman et al., 2010) in the field of sustainability, corporate social responsibility and environmental reporting as it is a sophisticated technique that shapes the qualitative data to a quantitative flavor. Based on climate change reporting literature, the content analysis has been divided into five broad categories namely, climate change risk, GHG emission accounting, energy consumption accounting, reduction \& cost, and governance. Then an unweighted Climate Change Disclosure Index (CCDI) has been constructed and used to understand the climate change disclosure level practiced by selected companies listed in DSE. Every disclosed item of the CCDI has a binary value e.g. either 1or 0 . Thus, the CCDI score has a minimum value of " 0 " and a maximum value of " 28 ". 


\section{Findings and analysis of the study}

\subsection{Overview of CCDI on the study}

Table 1 summarizes the descriptive statistics of the climate change disclosure indices. On average, each sample company has disclosed only three (3.68\%) items out of the maximum 28 items. The maximum score is 12 , minimum 0 , and the mode score is 1 . Twenty-four of the disclosing companies had a CCDI i.e.1, representing 24 companies out of 82 companies only disclose only one item of the selected 28 items. It is also found that 73 out of 82 companies disclosed at least one item about climate change in their annual reports. It is also found that $11 \%$ of the selected sample companies do not disclose any climate change related information on the face of their annual reports.

Over a course of a decade, several studies (Masum et al., 2019; Dey et al., 2017; Nurunnabi, 2016; Rahman et al., 2010) including this current study all found relatively poor disclosure level on climate change in Bangladesh. This confirms the issue of climate change receiving very poor attention from organizations in Bangladesh. In this regard, Fijałkowska et al., (2018) empirical study on Central and Eastern European Countries confirmed the reluctance of Corporate Social and Environmental engagement by the Bank. The study also mentioned lack of attention and communication about corporate accountability to society and environment are reason for such kind of reluctance. Belal and Cooper (2011) stated that lack of knowledge and training is accountable for reluctance of reporting. They also mentioned that fear of bad publicity and criticism from media and stakeholder deter corporate from environmental reporting.

Table 1. Descriptive statistics of climate change disclosure indices (CCDI)

\begin{tabular}{lll}
\hline & & Percentage \\
\hline Total Sample companies & 82.00 & $100.00 \%$ \\
No. Of companies disclosing at least 1 item & 73.00 & $89.00 \%$ \\
Total no. of non-disclosing companies & 9.00 & $11.00 \%$ \\
Mean CCDI (inclusive of non-disclosing & 3.02 & $3.68 \%$ \\
companies) & & \\
Median CCDI & 2.00 & $2.44 \%$ \\
Minimum CCDI & 0 & \\
Maximum CCDI & 12.00 & \\
Range & 12.00 & \\
First Quartile & 1.00 & \\
Third Quartile & 4.00 & \\
Mode CCDI & 1.00 & \\
No. Of companies with Mode CCDI & 24.00 & \\
\end{tabular}

Vol. 18, No. 3 
Figure 1. Box and Whisker plot of CCDI of sample companies

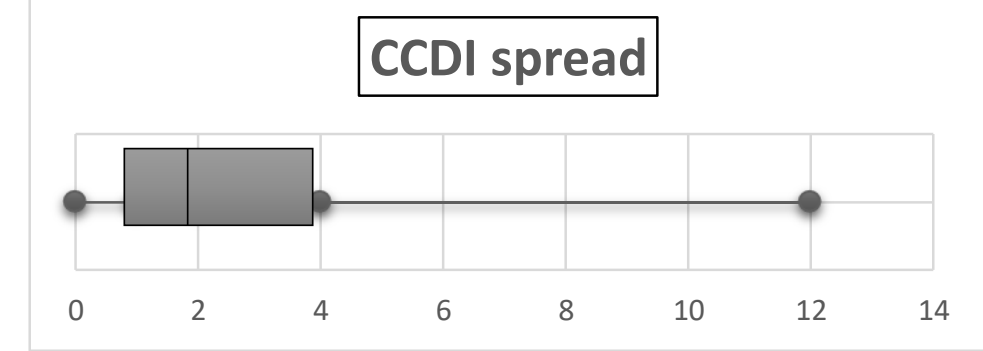

Figure 1 is a box and whisker plot showing the spread of climate change disclosure indices (CCDI) of all the 82 companies. The minimum score is 0 and the maximum is 12 . The distribution shows that $50 \%$ (42) of the companies have a very low CCDI between 0 to 2 . The third quartile at 4 represents that $75 \%$ of the companies have a CCDI score of maximum 4 . The fourth quartile represents that $25 \%$ of the companies have CCDI ranging from 4 to 12 which are rather spread out within a longer range of 8. The Distribution of CCDIs is positively skewed which means the scores are more spread out towards the rights. In other words, the frequency of higher scores was lower than the frequency of lower scores. Most companies have scores between 0 to 4.

Figure 2. Industry-wise average climate change disclosure indices (CCDI)

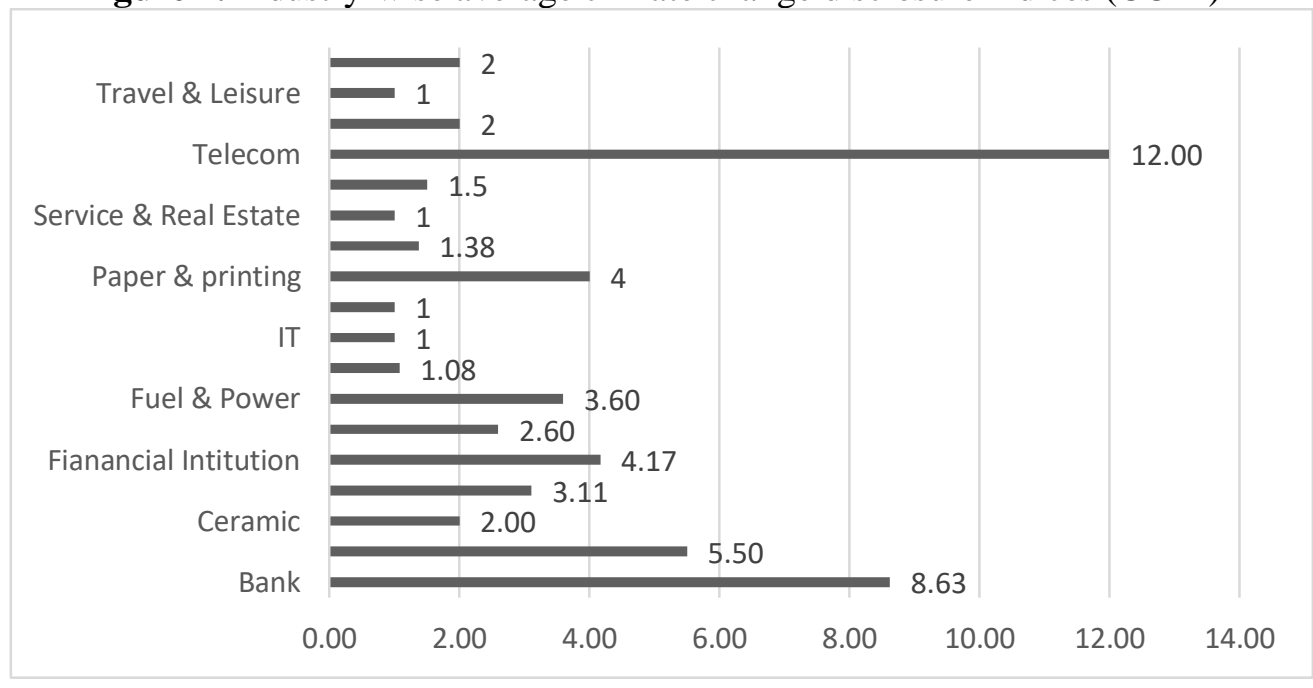

Note: Maximum possible score is 28

\subsection{Industry-wise average climate change disclosure indices (CCDI)}

Figure 2 shows a comparison between the industry wise climate change disclosure indices (CCDI). From figure two, it is clearly visible that the telecommunication company pays more attention to climate change issues with the highest CCDI score 
of 12 although it is below $50 \%$ of the possible maximum score. And the second highest (8.63) CCDI score lies on banking industry followed by the cement industry (5.5). On the contrary, IT, Jute, Service \& Real estate and Travel \& Leisure industries only have a CCDI score of 1 . We have observed very poor CCDI score for the highly polluted industries i.e. Fuel \& Power (CCDI 3.6), Paper \& printing (CCDI 4), Engineering (CCDI 3.11), Tannery (CCDI 1.5), Textile (CCDI 2) which also complied with the findings of Dey et al. (2017) and Nurunnabi (2016), although our findings have contradiction to the findings of Bae et al. (2013). Margolis et al. (2007) also added that enforceable reporting rules for entire industry encourage business entities to act reasonably and responsibly. The study also emphasized mandating itemization of certain social responsibility for entire industry. Belal and Cooper (2011) mentioned the necessity of legal requirement for Corporate social reporting for the developing countries. They also mentioned that unlike many other developed counties, Bangladesh did not enforce corporate social reporting as mandatory reporting practice yet.

This scenario portrays the vulnerability in the climate change reporting practices of the country. About a decade ago, Azizul and Deegan (2005) interviewed ready-made garments sectors' social and environmental discourse practices and found poor social issues which are also visible in 2019 (Masum et al., 2019). After a decade, no significant change has been observed in 2017 (Masum et al., 2017) and even in the current study as the textile industry has a mean CCDI score of only two out of a maximum possible score of twenty-eight. This finding also complies with the assumptions of socio-political theories as it assumes negative association between the environmental performances and "soft" claim commitment to the environment which are not readily verifiable (Clarkson et al., 2008 cited by Cotter et al., 2012).

Table 2. Category wise disclosure level of climate change by sample companies

\begin{tabular}{|c|c|c|c|}
\hline Category & $\begin{array}{c}\text { Total } \\
\text { actual } \\
\text { disclosures }\end{array}$ & $\begin{array}{c}\text { Maximum possible } \\
\text { disclosures (n*total } \\
\text { disclosure item in each } \\
\text { category) }\end{array}$ & $\begin{array}{l}\text { Percentage } \\
(\%)\end{array}$ \\
\hline $\begin{array}{l}\text { Climate } \\
\text { risk/opp./other }\end{array}$ & 80 & $574(82 * 7)$ & 13.94 \\
\hline GHG emission accounting & 1 & $574(82 * 7)$ & 0.17 \\
\hline $\begin{array}{ll}\text { Energy } & \text { Consumption } \\
\text { Accounting } & \end{array}$ & 71 & $410(82 * 5)$ & 17.32 \\
\hline Reduction and Cost & 83 & $574(82 * 7)$ & 14.46 \\
\hline Governance & 13 & $164(82 * 2)$ & 7.93 \\
\hline
\end{tabular}

\subsection{Category-wise average climate change disclosure indices (CCDI)}

Table 2 shows climate change disclosure level of companies within each category. The overall picture of the disclosure level at every category is rather grim. With respect to its corresponding base (574), most disclosures are made about climate 
change reduction strategies and associated cost. Just opposite to that is the disclosure level of GHG emission accounting with only 1 disclosure out of the maximum possible disclosure score of 410 . This finding is consistent with Rahman et al., (2010) and it does make sense to say that as one of the lowest contributors to climate change but one of the worst victims of climate change effects, companies in Bangladesh are more focused into taking actions to mitigate climate change rather than to disclose about their relatively low GHG emission level. Low GHG disclosure level may also be due to lack of stakeholder demand from an emerging country like Bangladesh where the literacy rate is still low or due to lack of statutory regulation with respect to GHG emission. 80 disclosures regarding climate change related risk, opportunities, and other related issues have been made against the maximum total score of 574 that would have been the case if all 82 sample companies made disclosures in all the 7 items with respect to that category. Other climate related issues included environmental certification from the Department of Environment (DOE), certification of ISO 14001:2004, partnership with Global Climate Change Partnership Fund etc.

The Governance category received a score of 13 out of 164.13 companies disclosed about the governing body responsible for overseeing climate change related issues, however, no disclosure was made about the mechanism through which such monitoring has been done. The 'Energy Consumption Accounting' category scored 71 out of 410. All the disclosures in this category have been made for a single item only namely, 'energy consumption compared with previous years. The companies disclosed their energy consumption in monetary values in comparison with previous years. Rest all items within this category gets no attention from the companies. It is important to note that the study observed qualitative disclosures about environmental/climate change issues to be more common among the companies in Bangladesh rather than quantitative disclosures, which is similar to the findings of Rahman et al. (2010). In a culture of non-accountability and meager external regulations (Nurunnabi, 2016), qualitative disclosures can be an easy disguise to unsatisfactory environmental performance. For instance, it is for the companies to say that they are concerned about environmental degradation and spoof the stakeholders into believing they really do. Quantitative disclosures, on the other hand, forms a more solid record of their activities which the companies may be held to account for and which can only be made if the companies have really engaged in that action. Therefore, making qualitative disclosures can serve as a cunning way to manage a good corporate image, without disclosing many quantifiable actions that may be subject to public criticism.

These findings also matched with legitimacy theory which assumes that a business entity needs to execute its operation within the prevailing norms or standards of the society. Therefore, the business entities consecutively operate to seek legitimacy which is conferred by that particular society based on the social contract between the 
business and society (Cotter et al., 2012). Since Bangladesh has a culture of nonaccountability and meager external regulations (Nurunnabi, 2016), governance level score on climate change reporting is very low (only $7.93 \%$ ).

\section{Conclusion}

This research has been intended to find out the climate change reporting practices in Bangladesh. In doing so, Content analysis has performed based on the annual reports of 82 sample companies. As per expectation and consistent with the finding of previous studies (Rahman et al., 2010; Nurunnabi, 2016) the results are unsatisfactory. The average climate change disclosure index stands to be only 3.02 out of a maximum score of 28 which is only $3.68 \%$. The maximum score is 12 which has been scored by Grameen phone ltd and Islami Bank Bangladesh Ltd. The banking industry CCDI average is 8.63. Although not satisfactory enough, however, all the sample banks have disclosed at least minimum 7 items, largely due to their compliance with the Green Banking policy set by Bangladesh Bank. Surprisingly, highly polluting industries such as fuel and power, tannery, engineering, cement, etc. all showed staggeringly low disclosure practice which gives an indication of an extremely poor level of regulation for climate change related issues in Bangladesh. Nevertheless, companies have mostly disclosed their climate reduction strategies and cost-related issues followed by climate change-related risk and opportunities. Disclosures are found to be more qualitative in nature than quantitative. Only 1 disclosure is found in the GHG Accounting category and except for disclosure in 1 item (energy consumption compared with previous years) all other items in 'Energy consumption Accounting' got no disclosures at all. In a culture of non-accountability and poor regulation, qualitative disclosures could be used as a disguise for inadequate environmental performance as there are no exact quantitative figures that they could be held accountable for. However, on a different note, poor GHG emission accounting could also be due to the emission quantity being too insignificant to be disclosed. As one of the worst affected victims of climate change reported by World Bank in 2014, companies in Bangladesh may be more focused on mitigating climate change than disclosing about their scanty GHG emission level.

The findings reveal that still the polluting industries become far behind regarding the climate change issues. In addition, the non-polluting industries are performing comparatively well with the climate changing issues but with a very minimum level. The study contributes in numerous aspects, firstly, the polluting industries become more accountable to disclose more information on their corporate reports - these will engage them more in dealing with climate change issues. Secondly, the regulatory bodies may have the ideas regarding the policies of corporate climate change reporting. Thirdly, the academicians can initiate more research agenda on corporate sustainability as it directly tied with climate change issues. And finally, the study 
will create awareness to all the stakeholders of the climate change issues so that a holistic approach can be used to cope up the vulnerability in climate change.

The findings of the study provide ample opportunity to explore some of the new and emerging issues in corporate reporting. For that we need to answer the questions stated below:

- Which aspect of the corporate governance stimulates an entity to disclose more climate change information on corporate reporting especially in developing countries?

- Is the corporate climate change reporting value relevant in developing countries?

- Is corporate climate change reporting influence the corporate performance of emerging economies?

These questions definitely create ample research opportunity in corporate climate reporting literature in developing countries like Bangladesh indeed.

\section{References}

Ahmad, N.N.N. \& Hossain, D.M. (2015) "Climate change and global warming discourses and disclosures in the corporate annual reports: A study on the Malaysian companies", Procedia-Social and Behavioral Sciences, vol. 172: 246-253

Allen, M. W., \& Craig, C. A. (2016) "Rethinking corporate social responsibility in the age of climate change: A communication perspective", International Journal of Corporate Social Responsibility, vol. 1(1), 1

Amran, A., Periasamy, V. \& Zulkafli, A.H. (2014) "Determinants of climate change disclosure by developed and emerging countries in Asia Pacific", Sustainable Development, vol. 22(3): 188-204

Azizul Islam, M. \& Deegan, C. (2008) "Motivations for an organisation within a developing country to report social responsibility information: Evidence from Bangladesh", Accounting, Auditing \& Accountability Journal, vol. 21(6): 850-874

Bae Choi, B., Lee, D. \& Psaros, J. (2013) “An analysis of Australian company carbon emission disclosures", Pacific Accounting Review, vol. 25(1): 58-79

Belal, A.R. (2000) "Environmental reporting in developing countries: empirical evidence from Bangladesh", Eco-Management and Auditing: The Journal of Corporate Environmental Management, vol. 7(3): 114-121

Belal, A. R. \& Cooper, S. (2011) "The absence of corporate social responsibility reporting in Bangladesh", Critical Perspectives on Accounting, vol. 22(7): 654-667 
Blacconiere, W.G. \& Patten, D.M. (1994) "Environmental disclosures, regulatory costs, and changes in firm value", Journal of Accounting and Economics, vol. 18(3): 357-377

Brown, N. \& Deegan, C. (1998) "The public disclosure of environmental performance information - a dual test of media agenda setting theory and legitimacy theory", Accounting and Business Research, vol. 29(1): 21-41

Clarkson, P.M., Li, Y., Richardson, G.D. \& Vasvari, F.P. (2008) "Revisiting the relation between environmental performance and environmental disclosure: An empirical analysis", Accounting, Organizations and Society, vol. 33 (4-5): 303-327

Cotter, J., Lokman, N. \& Najah, M.M. (2011) "Voluntary disclosure research: Which theory is relevant", The Journal of Theoretical Accounting Research, vol. 6(2): 7-95

Deegan, C. \& Rankin, M. (1999) "The environmental reporting expectations gap: Australian evidence", The British Accounting Review, vol. 31(3): 313-346

Dey, P.K., Nakib, M. \& Dutta, P. (2017) "Climate change disclosures in the annual reports: Evidence from Bangladesh", Asian Journal of Finance \& Accounting, vol. 9(2)

Dunn, S. (2002) "Down to business on climate change: an overview of corporate strategies", GSE Research, p.10.

Eckstein, D., Hutfils, M.L. \& Winges, M. (2018) Global Climate Risk Index 2019: Who Suffers Most From Extreme Weather Events? Weather-related Loss Events in 2017 and 1998 to 2017, Germanwatch Nord-Süd Initiative eV. [Accessed 10 Apr. 2019].

Eleftheriadis, I.M. \& Anagnostopoulou, E.G. (2015) "Relationship between corporate climate change disclosures and firm factors", Business Strategy and the Environment, vol. 24(8): 780-789

Ferguson, J., Sales de Aguiar, T.R. \& Fearfull, A. (2016) "Corporate response to climate change: language, power and symbolic construction", Accounting, Auditing \& Accountability Journal, vol. 29(2): 278-304

Fijałkowska, J., Zyznarska-Dworczak, B. \& Garsztka, P. (2018) "Corporate socialenvironmental performance versus financial performance of banks in Central and Eastern European countries", Sustainability, vol. 10(3): 1-22

Freedman, M. \& Jaggi, B. (1988) "An analysis of the association between pollution disclosure and economic performance", Accounting, Auditing \& Accountability Journal, vol. 1(2): 43-58

Glennon, R. (2017) "The unfolding tragedy of climate change in Bangladesh" [online] Available at: https://blogs.scientificamerican.com/guest-blog/theunfolding-tragedy-of-climate-change-in-bangladesh/ [Accessed 7 Apr. 2018]

Gray, R., Javad, M., Power, D. M., \& Sinclair, C. D. (2001) "Social and environmental disclosure and corporate characteristics: A research note and extension", Journal of Business Finance \& Accounting, vol. 28(3-4): 327-356 
Hackston, D. \& Milne, M.J. (1996) "Some determinants of social and environmental disclosures in New Zealand companies", Accounting, Auditing \& Accountability Journal, vol. 9(1): 77-108

Haque, S. \& Deegan, C. (2010) "Corporate climate change-related governance practices and related disclosures: evidence from Australia", Australian Accounting Review, vol. 20(4): 317-333

Hossain, M.M., Alam, M., Islam, M.A. \& Hecimovic, A. (2015) "Do stakeholders or social obligations drive corporate social and environmental responsibility reporting? Managerial views from a developing country", Qualitative Research in Accounting \& Management, vol. 12(3): 287-314

Huisingh, D., Zhang, Z., Moore, J.C., Qiao, Q. \& Li, Q. (2015) "Recent advances in carbon emissions reduction: policies, technologies, monitoring, assessment and modeling", Journal of Cleaner Production, vol. 103: 1-12

Ieng Chu, C., Chatterjee, B. and Brown, A. (2012) "The current status of greenhouse gas reporting by Chinese companies: A test of legitimacy theory", Managerial Auditing Journal, vol. 28(2): 114-139

Imam, S. (2000) "Corporate social performance reporting in Bangladesh", Managerial Auditing Journal, vol. 15(3): 133-142

Jeswani, H.K., Wehrmeyer, W. \& Mulugetta, Y. (2008) "How warm is the corporate response to climate change? Evidence from Pakistan and the UK", Business Strategy and the Environment, vol. 17(1): 46-60

Johnston, D.M., Sefcik, S.E. \& Soderstrom, N.S. (2008) "The value relevance of greenhouse gas emissions allowances: An exploratory study in the related United States SO2 market", European Accounting Review, vol. 17(4): 747-764

Kabir, H. \& Akinnusi, D.M. (2012) "Corporate social and environmental accounting information reporting practices in Swaziland", Social Responsibility Journal, vol. 8(2): 156-173

Khan, H.U.Z., Azizul Islam, M., Kayeser Fatima, J. \& Ahmed, K. (2011) “Corporate sustainability reporting of major commercial banks in line with GRI: Bangladesh evidence", Social Responsibility Journal, vol. 7(3): 347-362

Luo, L., Tang, Q. \& Lan, Y.C. (2013) "Comparison of propensity for carbon disclosure between developing and developed countries: A resource constraint perspective", Accounting Research Journal, vol. 26(1): 6-34

Margolis, J.D., Elfenbein, H.A. \& Walsh, J.P. (2007) "Does it pay to be good? A meta-analysis and redirection of research on the relationship between corporate social and financial performance", Ann Arbor, 1001, pp. 48109-1234.

Masud, M., Bae, S. \& Kim, J. (2017) "Analysis of environmental accounting and reporting practices of listed banking companies in Bangladesh", Sustainability, vol. 9(10), 1717: 1-19

Masum, M.H., Uddin, M.M., Ahmed, H. \& Uddin, M.H. (2019) "Corporate Social Responsibility Disclosures and Corporate Performance: Evidence from the listed Companies in Bangladesh", Academy of Strategic Management Journal, vol. 18(2): 1-16 
Masum, M.H., Fakir, A.N.M.A. \& Hussain, M.K. (2017) "Multi-facet performance measurement system for textile industries: a comprehensive study from Bangladesh", Research Journal of Finance and Accounting, vol. 8(10): 87-94

Ministry of Environment and Forests (2009) Bangladesh Climate Change Strategy and Action Plan 2009. Government of the People's Republic of Bangladesh, Dhaka, Ban(xviii), 76, Accessed from https://www.iucn.org/downloads/bangladesh_climate_change_strategy_an d_action_plan_2009.pdf

Nasa, n.d.. Scientific Consensus: The earth's climate is warming. Accessed on 8 May 2018, https://climate.nasa.gov/scientific-consensus/

Nasa, n.d., What's in a name? Weather, global warming, and climate change. Accessed on 8 May 2018, https://climate.nasa.gov/resources/globalwarming/

Nurunnabi, M. (2016) "Who cares about climate change reporting in developing countries? The market response to, and corporate accountability for, climate change in Bangladesh", Environment, Development and Sustainability, vol. 18(1): $157-186$

Orlitzky, M., Schmidt, F.L. \& Rynes, S.L. (2003) "Corporate social and financial performance: A meta-analysis", Organization Studies, vol. 24(3): 403-441

Rahman Belal, A., Rezaul Kabir, M., Cooper, S., Dey, P., Ahmed Khan, N., Rahman, T. \& Ali, M. (2010) "Corporate environmental and climate change disclosures: empirical evidence from Bangladesh", Research in Accounting in Emerging Economies, vol. 2010: 145-167

Rahman Belal, A. \& Momin, M. (2009) "Corporate social reporting (CSR) in emerging economies: A review and future direction", Research in Accounting in Emerging Economies, vol. 2009: 119-143

Rainsbury, E.A., Hao, G. \& Yang, M. (2016) "Environmental reporting disclosures of Shandong listed companies in China", New Zealand Journal of Applied Business Research, vol. 14(2): 43-59

Sobhani, F.A., Amran, A. \& Zainuddin, Y. (2009) "Revisiting the practices of corporate social and environmental disclosure in Bangladesh", Corporate Social Responsibility and Environmental Management, vol. 16(3): 167-183

The World Bank (2014) Bangladesh: Community-Driven Attempts to Build Climate Change Resiliency, Accessed on 7 April 2018, http://www.worldbank.org/en/news/feature/2014/07/17/bangladesh-comm unity-driven-attempts-to-build-climate-change-resiliency 


\section{Appendix}

Overview of sample design

\begin{tabular}{|c|c|c|c|}
\hline$\#$ & Name of the Industry & $\begin{array}{c}\text { Population } \\
(\mathbf{N})\end{array}$ & $\begin{array}{c}\text { Random Sample } \\
(\mathbf{n})\end{array}$ \\
\hline 1 & Bank & 30 & 8 \\
\hline 2 & Cement & 7 & 2 \\
\hline 3 & Ceramics Sector & 5 & 2 \\
\hline 4 & Engineering & 36 & 9 \\
\hline 5 & Financial Institutions & 23 & 6 \\
\hline 6 & Food \& Allied & 18 & 5 \\
\hline 7 & Fuel \& Power & 18 & 5 \\
\hline 8 & Insurance & 47 & 12 \\
\hline 9 & IT Sector & 8 & 2 \\
\hline 10 & Jute & 3 & 1 \\
\hline 11 & Miscellaneous & 12 & 3 \\
\hline 12 & Paper \& Printing & 2 & 1 \\
\hline 13 & Pharmaceuticals \& Chemicals & 29 & 8 \\
\hline 14 & Services \& Real Estate & 4 & 1 \\
\hline 15 & Tannery Industries & 6 & 2 \\
\hline 16 & Telecommunication & 2 & 1 \\
\hline 17 & Textile & 50 & 13 \\
\hline \multirow[t]{2}{*}{18} & Travel \& Leisure & 4 & 1 \\
\hline & Total & 304 & 82 \\
\hline
\end{tabular}

(Source: www.dsebd.org (accessed on 23.04.2018)) 